\title{
As Canções Inumanas
}

\author{
Gisela Castro ${ }^{1}$ \\ Escola Superior de Propaganda e Marketing - SP \\ giselag@espm.com.br
}

\begin{abstract}
Resumo: $O$ presente artigo apresenta algumas das principais idéias que sustentam a pertinência da investigação acerca da recepção musical nas práticas culturais contemporâneas. A discussão acerca das novas posturas de escuta desenvolvidas a partir da associação entre música e tecnologia aponta para uma dramática desnaturalização do ouvido humano. Ressaltando o papel ativo do ouvinte, verificamos que a sensibilidade humana, longe de ser natural e portanto acabada e imutável, expande seu potencial sensível ao ser estimulada sinteticamente, dando origem a novas possíveis configurações de sentido.
\end{abstract}

Abstract: The present article discusses some of the main ideas which support the relevance of investigating musical reception within contemporary cultural practices. This discussion leads to the acknowledgement of a dramatic desnaturalization of the human ear, wheb new modes of listening are brought about by the association between music and cutting edge technology. By highlighting the active role of the listener, one can see that human sensibility is not natural or finished and unchangeable. Its sensitive potential can be synthetically stimulated, generating new possible configurations of meaning.

Resumen: El presente artículo propone algunas de las principales ideas que sustentan cuan pertinente es la investigación sobre la percepción musical en las prácticas culturales contemporáneas. La discusión sobre las nuevas posturas de la escucha, desenvuelta a partir de la asociación entre música y tecnología indican una dramática desnaturalización del oído humano. Al destacar el papel activo del oyente, verificamos que la sensibilidad humana expande su potencial perceptivo cuando estimulada sinteticamente, produciendo así nuevas y posibles configuraciones de escucha, contrariando cualquier propuesta de que esta sea natural, acabada e inmutable.

\footnotetext{
${ }^{1}$ Psicóloga (IP/UFRJ), Doutora em Comunicação e Cultura (ECO/UFRJ), Pesquisadora do Núcleo de Pesquisa em Comunicação e Práticas de Consumo da ESPM-SP, tendo atuado também como pesquisadora do Programa de Pós-Graduação em Comunicação Social da PUC-Rio.
} 
Résumée: Le présent article présente quelques des principaux idées sur l'investigation autour de la perception musicale dans les pratiques culturelles contemporaines. La discussion autour des nouveau rapports de $l$ 'écoute développe 'a partir de l'association entre musique et technologie signale pour une dramatique dénaturalisation de l'oüe human .Il faut souligner l'aspect active de l'auditeur, nous verifions que la sensibilité humaine loin d être naturelle et pourtant achevée et immuable peut elargir son potentiel sensible du fait d'être stimule artificiellement et donner naissance a des nouvelles possibilités de la perception.

Palavras-Chaves: Música, escuta, comunicação, tecnologia

Keywords: Music, listening, communications, technology.

Palabras claves: Música, escucha comunicación, tecnología.

Mots-Clés: Musique, écoute, communication, technologie.

Este início de um novo século - e milênio - vem sendo marcado por algumas transformações sociais de grande magnitude. Há apenas poucas décadas, participamos da instauração de uma nova topologia - o ciberespaço - da consolidação de um novo regime de realidade - a realidade virtual - e do crescimento exponencial da rede mundial de computadores, estabelecendo uma forte pregnância da comunicação mediada por computador (CMC), propiciando novas modalidades de interação inter e ultra-subjetivas diversos tipos de jogos comunicacionais on line e coletivos virtuais inteligentes.

Estas inovações trazem em seu bojo uma reconfiguração significativa na experiência humana. Derrick DeKerckhove² ${ }^{2}$ diretor do centro de pesquisas em Cultura e Tecnologia da Universidade de Toronto, denomina inteligência conectada esta modalidade de experiência onde, segundo percebe, o ponto de vista é substituído pelo ponto de existência (point of being). Ocorre que, para integrar este coletivo virtual o usuário deve estar conectado à rede, logo sua existência passa a ser configurada pelo nódulo que realiza na trama rizomática

\footnotetext{
2 Em A Pele da Cultura. Lisboa: Relógio D’Água, 1997.
} 
da web, sem centro nem periferia. Ao discutir a transição do ponto de vista para o ponto de existência, Kerckhove reinventa a máxima cartesiana como estou conectado, logo existo.

O ponto de existência tem como característica estabelecer um tipo de vínculo ou conexão que dispensa os aportes identitários que marcam as interações presenciais no mundo real. Não se trata necessariamente de serem estes vínculos mais tênues, superficiais ou efêmeros do que aqueles estabelecidos fora da rede, mas sim de uma modalidade diferente de vinculação, especialmente porque estão abolidas as distâncias geográficas e as censuras inerentes à identidade pessoal e ao corpo próprio, figuras do mundo material que se esmaecem no virtual.

Como a comunicação na rede é hoje primordialmente textual - embora esteja se tornando crescentemente multimídia - nossos corpos são solicitados apenas para as funções mínimas de digitar o teclado e manipular o mouse, ler ou ver imagens na tela e eventualmente ouvir através das caixas de som os dados que vão surgindo. Sem o peso excessivo do corpo, sem as limitações e constrangimentos inerentes à própria corporeidade, grandes contingentes de usuários da web sentem-se livres para tecer múltiplas identidades on line.

Alguns autores apontam neste fator justamente um dos grandes atrativos do ciberespaço. Sherry Turkle3 ${ }^{3}$ chega mesmo a propor o fim da ilusão da unidade do self, atomizado na profusão de ciber-subjetividades que perambulam em chat-rooms, salas de cibersexo, grupos de discussão on-line e demais parlatórios virtuais onde brotam, interagem e eventualmente desaparecem sem deixar resíduos materiais.

Mais dramaticamente, estas ciber-subjetividades habitam também os cibermundos de fantasia, ou MUDs (sigla em inglês para multi-user domain, mas que pode ser lida como a palavra lama, remetendo à lama primordial de onde teria brotado a vida). Inicialmente criados para abrigar versões virtuais do role-playing game Dungeons and Dragons, muito popular nos EUA em fins

\footnotetext{
3 Em Life on the Screen. New York: Simon and Schuster, 1995.
} 
da década de 70 e no Brasil dos anos 80, os MUDs se metamorfosearam em diferentes sentidos, continuando a atrair um grande número de participantes em todo o mundo. O que sustenta um MUD são os personagens que ele abriga, geralmente figuras lendárias como magos, bruxos, monstros e animais, além do ensejo coletivo de construí-los e perpetuá-los nestes cibermundos de fantasia compartilhada.

Sem aderir plenamente à visão de Turkle de que estaríamos constituindo uma nova e importante arena virtual para complexas experimentações mentais - com o eu fragmentado em múltiplos ciber-egos: homem, mulher, mais velho ou mais novo, animal, figura lendária, etc. - Margaret Wertheim 4 adverte para os perigos de que, ao invés de utilizarmos o ciberespaço para revitalizar nossas vivências de comunidade e coletividade - como um novo portal para a utopia da comunhão universal - poderíamos cair em um novo tipo de escapismo e individualismo, ao qual denominou cyberselfishness, ou ciber-egoísmo.

Algumas inquietações surgem a partir destas práticas. Qual será o significado desta célere torrente de identidades múltiplas que hoje circula pela web? Quais as necessidades que engendram estas ciber-subjetividades pontuais contemporâneas?

Estilhaçado ("partiu-se em mim o espelho em que me revia idêntico..." 5) Fernando Pessoa foi levado a criar, nos anos 30, o heterônimo. Estaremos nós agora no ciberespaço espelhando um outro estilhaçamento? Ou será que estamos em mutação, sendo os novos contornos possíveis percebidos através destes sinais que, por serem apenas indiciais, nos parecem inquietantes?

Será este ciber-impressionismo subjetivo mais uma faceta da dessubstancialização do mundo que foi desvelada pela física quântica ao penetrar no âmago da matéria, onde não há formas estáveis ou definidas, onde pulsa o

\footnotetext{
4 Em The Pearly Gates of Cyberspace: a history of space from Dante to the Internet. New York: Norton, 1999.

5 Lisbon Revisited, in: Obra Poética, vol único. Rio de Janeiro:Ed. Nova Aguilar, 1998.
} 
acaso6? Será que, como indaga Sueli Rolnik7, "a figura moderna da subjetividade, com sua crença na estabilidade e sua referência identitária, agonizante desde o final do século XIX, estaria chegando ao fim?” Ou será apenas que estamos nos alienando do lento e laborioso processo de pensarcriar, de engajarmo-nos na (des)contínua renovação de nós mesmos e do mundo à nossa volta, utilizando as múltiplas experimentações no mundo virtual como escapismo às tensões e contradições do mundo real, apenas?

$\mathrm{Na}$ virada do século XX as vanguardas identificavam nas tradições do passado a opressão, aquilo do qual era preciso se libertar, fundando o novo como valor em si e identificando no presente o berço dos novos possíveis. $\mathrm{O}$ futuro seria então o momento de emancipação, quando se daria a comunhão universal dos homens livres. Este projeto trazia em seu bojo aspirações totalizantes, hoje vistas sob suspeita.

$\mathrm{Na}$ atualidade, a cena está mudada. O novo como valor já não funciona como antes, até porque na exacerbada aceleração do mundo contemporâneo corre-se o risco de vê-lo banalizado como mera e passageira novidade. Em meio à velocidade que caracteriza a rápida superação de tecnologias até então consideradas de ponta e, sobretudo, devido à própria implantação da lógica do consumo que fabrica uma voracidade crescente por novidades no mercado, faz-se relevante pensar se e como é possível opor resistência a esta lógica que parece reduzir-nos a um vazio subjetivo tão recorrente nestes tempos de capitalismo pós-industrial. Muniz Sodré analisa:

\footnotetext{
"A tecnologia compensa com sua plenitude eficiente a insuficiência do homem - a mesma insuficiência, aliás, alimentada pela ordem do consumo, cuja lógica (por arrastar a consciência num ciclo interminável de desejos) é a da insatisfação radical." 8
}

\footnotetext{
${ }^{6}$ Luiz Alberto Oliveira no artigo Por um novo materialismo? in: TAVARES D'AMARAL, M. (org.) Contemporaneidade e Novas Tecnologias. Rio de Janeiro: Sette Letras, 1996.

7 No artigo Toxicômanos de identidade: subjetividade em tempo de globalização in: LINS, Daniel (org.) - Cultura e Subjetividade: saberes nômades. São Paulo: Papirus, 1998 p. 20. ${ }_{8}^{8}$ Antropológica do Espelho: uma teoria da comunicação linear e em rede. Op. Cit. p. 78.
} 
Talvez a aceleração das transformações na ciência, na tecnologia e na arte seja de tal ordem que muitos se sentem hoje desorientados diante desta realidade em rápida transformação. Talvez a crescente sofisticação da tecnologia esteja tornando mais clara a dor narcísica da insuficiência do homem diante da aparente potência supra-humana das máquinas inteligentes. Talvez a própria imaterialidade do ciberespaço e a proliferação de próteses técnicas as mais diversas estejam tornando incompatíveis a concepção iluminista de mundo e de natureza humana, calcadas na substancialidade material objetiva e no sujeito psicológico individuado. Nas atuais esferas de experiências cognitivas coletivas e híbridas por excelência, os contornos habituais são desfeitos, ensejando esboços agora ultra-humanos.

Para Muniz Sodré, "a substancialidade orgânica do ultra-humano é feita de informação e capital." 9 Sua descrição nos parece apontar com precisão o cruzamento entre tecnologias informacionais e fluxos do capital num mundo cada vez mais globalizado. A globalização ameaça aniquilar diferenças culturais, reduzindo-as a nichos de mercado, bem como sufocar experimentações individuais que escapem à lógica dos padrões estereotipados de identidades prêt-à-porter, padrões estes baseados em perfis de consumidor onde figuras glamourizadas são veiculadas como ícones. Diante destas figuras e do glamour da exposição na mídia, a existência comum e corriqueira pode parecer destituída de sentido, induzindo assim à lógica perversa do consumo que, ao reduz ser a ter ou a aparentar ser, alimenta ad eternum a voracidade insaciável.

Com aparente triunfo do capitalismo após o desmantelamento da polarização mundial da guerra fria, aliado à constituição das grandes redes globais de telecomunicação e de infovias mundiais, a lógica da globalização parece se impor como a única possível. Guattari oportunamente denomina o processo de globalização econômica de capitalismo mundial integrado - CMI

\footnotetext{
9 Idem, p. 77.
} 
- de modo a recolocar a idéia de que, apesar de ser a lógica predominante, esta não é a única possível.

"O capitalismo pós-industrial que, de minha parte, prefiro qualificar como Capitalismo Mundial Integrado (CMI) tende, cada vez mais, a descentrar seus focos de poder das estruturas de produção de bens e de serviços para as estruturas produtoras de signos, de sintaxe e de subjetividade, por intermédio, especialmente, do controle que exerce sobre a mídia, a publicidade, as sondagens, etc." 10

Focos de resistência à pretensa inexorabilidade desta lógica regulada pela voracidade do lucro, visam constituir processos alternativos de subjetivação na experimentação social de trocas múltiplas entre indivíduos, grupos e meios de comunicação.

Howard Rheingold ${ }^{11}$, pioneiro na experiência de comunidades virtuais, denomina smart mobs a estas multidões ou coletivos inteligentes que se aglutinam na rede em torno de causas que eticamente lhes parecem importantes. Estas constelações de subjetividades conectadas estão reinventando o ativismo e a contracultura através do ciberespaço.

Trazendo de Foucault ${ }^{12}$ a noção de vida como obra de arte, afirmamos que as motivações para a constituição de linhas de vida que escapem aos meios utilizados pelo CMI na sociedade de controle ${ }^{13}$ são, necessariamente ou fundamentalmente, ético-estéticas. A liberdade seria, então, a confecção de estilo e a presença do estilo, a afirmação do pensamento. A noção de liberdade concebe como sua conseqüência um ir além das estruturas psicológicas, do

10 GUATTARI, Félix - As Três Ecologias. Campinas: Papirus, 1990 p. 31.

${ }_{11}$ Ver RHEINGOLD, Howard - Virtual Communities: homesteading on the electronic frontier, disponível para download na Internet. Ver também www.smartmobs.com, weblog de discussão do livro Smart Mobs: the next social revolution, do mesmo autor (consultado em abril/2003).

${ }^{12}$ E este, dos gregos, especialmente os estóicos, analisados em A História da Sexualidade, vol.2 O Uso dos Prazeres. Rio de Janeiro: Graal, 1994.

${ }_{13}$ Este é um conceito de Deleuze, a partir de William Burroughs. (ver Post-Scriptum sobre a sociedade de controle in Conversações. Rio de Janeiro: Editora 34, 1992). O controle, insidioso e contínuo, é exercido através de estratégias de marketing, da moratória ilimitada e da exigência de formação permanente, por exemplo. 
modelo iluminista de homem. Trata-se pois de novos estilos de pensamento e de vida. Trata-se, aqui neste trabalho, de tornar audíveis seus maquinismos éticos e estéticos.

Destacando o problema das artes, nesta questão do pensamento e da liberdade, investe-se na maneira como se daria fim à representação. Nas artes plásticas, por exemplo, inúmeros autores buscam expressar no visível das cores e dos planos, na imaterialidade da web art, na multi-dimensionalidade da instalação, na efemeridade das obras perecíveis e da performance, afetos do tempo, para isto precisando quebrar as forças da perspectiva, dos clichês, da narração.

Na música não é diferente: o fenômeno do som e notas, silêncio, eletrônica, explosão da palheta tímbrica, espacialização de massas e planos sonoros, micro-percepções, memórias de curta duração, inteligência artificial, ultra-dimensionamento de parâmetros, entrelaçam-se compondo linhas estéticas que pretendem fazer aparecer o molecular da sensação, acrescentando, como disse Deleuze, "novas variedades ao mundo"14.

Trata-se, no caso da arte, de um bloco de sensações: a própria expressividade da matéria (sonora, no nosso caso) que nos é dada a contemplar. Esta contemplação não é passiva, mas também ativa, sendo o receptor/ouvinte o intérprete último da mensagem/música, com a qual estabelece relações de sentido por vezes insuspeitadas pelo emissor/autor.

Operando em diferentes níveis, ou planos, a linguagem artística, ou mais precisamente para nós, a linguagem musical, parece engendrar um tipo de comunicação que não pode ser apreendido com base em modelos lineares do tipo emissor-código-meio-receptor. Interferências múltiplas parecem ocorrer em todos os estágios, simultaneamente. Guattari observa que: “a relação de um indivíduo com a música (...) pode acarretar um processo de percepção e

\footnotetext{
14 Em O que é a Filosofia, p. 227.
} 
sensibilidade inteiramente novo."15 Inspirados nesta idéia, propomos destacar o que estamos chamando posturas de escuta.

Quando a tecnologia se afirma como parte integrante do contexto cultural contemporâneo, a arte investe na diversidade dos meios tecnológicos para que sejam investigados e expandidos seus potenciais sensíveis. Percebese, por exemplo, um contínuo investimento na quebra das referências mais imediatas da música com a percepção humana, que estabelece um certo princípio de seleção a partir de suas próprias necessidades, hábitos e limitações. Trata-se de uma arte que tem consistentemente tomado o suporte tecnológico - e não somente o humano - como seu ponto de referência mais radical.

Uma referência nas explorações da nossa percepção aconteceu no seio da chamada cultura psicodélica, que se pode equiparar a uma outra épica exploração sua contemporânea - a espacial, que se iniciava naquela mesma época - ambas visando expandir os limites do homem. Esta cultura se embasou nas concepções de vários artistas e pensadores. Vamos nos ater aqui a dois deles: William Blake e Aldous Huxley.

O visionário William Blake, ao decantar a percepção humana, sempre limitada e imperfeita, refere-se aos cinco sentidos ao cunhar a frase que se tornou emblemática para a exploração que a geração dos anos 60 pregou e viveu: "If the doors of perception were cleansed, ever'thing would appear to man as it is... infinite" ${ }^{16}$.

As idéias de Blake inspiraram Aldous Huxley, que parafraseando o poeta intitulou um de seus livros The Doors of Perception: Heaven and Hell ${ }^{17}$. Esta obra precedeu, fundamentou e estimulou a cultura psicodélica: a aventura da busca, alteração e re-descoberta da percepção humana através da

\footnotetext{
${ }^{15}$ Em GUATTARI, F. e ROLNIK, S. Micropolítica: cartografias do desejo. Petrópolis: Vozes, 1986 p. 47.

16 "Se as portas da percepção estivessem devidamente purificadas, tudo assomaria aos olhos dos homens como deveras o é... infinito." Tradução: Augusto de Campos.

${ }_{17}$ Penguin Books, 1959. Editado no Brasil pela Ed. Globo, com o título de As Portas da Percepção.
} 
experimentação de estados alterados de consciência induzidos por substâncias psicoativas.

A escuta, talvez pela sua inexorabilidade, foi um dos sentidos mais intensamente explorados por esta aventura nesta época, iniciando talvez de maneira bastante abrupta e pela primeira vez na cultura ocidental um envolvimento expressivo da juventude com a experimentação na linguagem musical, sua interação com novas possibilidades de invenção musical, a longa formação do que aqui chamamos de uma nova postura de escuta. Emblemático desta relação é o fato de uma das bandas signatárias deste movimento chamar-se The Doors, em uma clara alusão a Blake e Huxley.

Um prolongamento daquela longa exploração dos sentidos feita ensejada na cultura psicodélica parece ser encontrado hoje em dia na chamada cena rave. Entendemos as raves como um dos modos de comparecimento da experimentação da cultura psicodélica em nossos dias, embora com contornos e propósitos diversos. Nestes eventos, o som de características hipnóticas em volume altíssimo, contraposto a outros fortes estímulos sensoriais, concorre fortemente para a indução dos efeitos desejados, incluindo a hipertrofia dos sentidos.

Mark Dery ${ }^{18}$ propõe o termo cyberdelia para designar o movimento de contracultura que se opera através do ciberespaço, nossa recém-aberta fronteira eletrônica. Nesta sua versão tecnológica, a nova psicodelia abriga experimentações alternativas como os ravers e os cyberpunks, bem como diversos movimentos de resistência - esta entendida em suas dimensões política, social, e cultural - configurados pelos coletivos inteligentes, tendo na apropriação da tecnologia um canal para transcender a esfera ordinária da experiência humana.

Se os modernos tinham como grande utopia a arte como modificadora da realidade, a desubstancialização do mundo promovida pelas tecnologias digitais não só, como dissemos, coloca em questão a própria noção de

\footnotetext{
${ }^{18}$ Em Escape Velocity: cyberculture at the end of the century. New York: Grove/Atlantic, 1995.
} 
realidade, como também tensiona o paradigma do humano. Pensadores contemporâneos não cessam de apontar as novas fronteiras que as imbricações com as tecnologias vêm descortinando para a subjetividade contemporânea.

As intuições de McLuhan sugerem que as ferramentas tecnológicas que inventamos e utilizamos funcionam como prolongamentos de nosso sistema nervoso, modificando o humano. Segundo sua análise, cada novo meio (mídia) delineia um novo modo de percepção. Os meios eletrônicos, seus fluxos transparentes e extremamente maleáveis, favorecem um tipo de imersão comparável àquela que experimentamos ao sermos perpassados pelo som. Desconsiderando o neo-humanismo a-político em McLuhan, que nos parece um tanto ingênuo, interessa-nos ressaltar a qualidade acústica da nova aldeia global que vislumbrou.

\begin{abstract}
"O novo meio-ambiente de informação simultânea e diversificada cria o homem acústico. Ele está envolvido pelo som (...) seu meioambiente é feito de informação simultânea de todos os tipos (...) Transmitidos à velocidade da luz, todos os eventos deste planeta são simultâneos. (...) o espaço acústico ou simultâneo não pode ser cortado em pedaços (...) Ele é ao mesmo tempo comprimido e indivisível." 19
\end{abstract}

Longamente dominante na cultura ocidental, o modelo visual seleciona e fixa o percebido em categorias confiáveis de re-conhecimento. De acordo com esta perspectiva, independente do sujeito que o percebe, o mundo é constituído por substâncias estáveis e individuadas, as quais podem ser analisadas uma a uma e classificadas em gênero, grau e espécie. Conceitos como contigüidade, semelhança e causalidade (causa-e-efeito) também estão associados a este modelo cognitivo, que opera num mundo já dado e espacializado.

19 McLuhan apud BENEDETTI, P. e DeHART, N. Forward Through the Rearview Mirror: Reflections on and by McLuhan. Cambridge, Massachussets: MIT Press, 1996 p. 46. 
Hoje este modelo parece conviver de perto com o modelo auditivo, que ao invés de fixar-se em objetos localizados ou eventos inteiros, está atento aos fluxos multi-direcionais do todo em (in)constante mutação. A tradicional separação sujeito/objeto deixa de fazer sentido, já que se trata de imersão e co-engendramento. No modelo auditivo está-se atento ao contexto externo e interno, ao antes e ao depois. Neste modo de cognição, oscilações expressivas, fluxos de intensidade, texturas tímbricas, formas efêmeras, contornos rítmicos surgem e se esvaem num jorro inexorável e diversificado. Noções como inacabamento, indeterminação, metaestabilidade e casualidade (acaso) entram em cena para descrever a complexidade do mundo assim percebido, composto por temporalidades.

Ao pensar a tecnologia a penetrar o campo do simbólico, mais notadamente o campo da música, é necessário questionar se o que está em jogo seria apenas um prolongamento tecnológico de nossa sensibilidade humana, como por exemplo na percepção de gamas de som que seriam inaudíveis mas que podem ser amplificadas tecnologicamente; ou uma modificação mais radical no processo de subjetivação, que desterritorializa os aportes do humano.

É neste sentido que se pode aludir à noção de psicotecnologias. Esta gama de pesquisas prolonga e atualiza os estudos de McLuhan, enfocando as complexas interações entre pensamento e tecnologia. Kerckhove trata como psicotecnologias as interações entre a psique humana e os sistemas eletrônicos de processamento de informação, os quais nos condicionam tanto em nível social quanto pessoal para "responder de acordo com critérios técnicos e não apenas psicológicos.”20

Apesar do tom behaviorista que sua análise por vezes assume e que nos parece excessivo, pensamos ser relevante considerar o tecnológico como importante re-configurador psicológico e social, especialmente ao enfocarmos

\footnotetext{
${ }^{20}$ Em A Pele da Cultura. Op. Cit. p. 275.
} 
aqui o papel da música contemporânea ao expandir e modificar a nossa sensibilidade.

Percebemos que as artes contemporâneas, e não somente a música vide, por exemplo, a web art - parecem instituir zonas de passagem nas fronteiras entre o humano e o não-humano. Deve-se, portanto, ressaltar a potência da arte como vetor de subjetivação. Traços de expressão e máquinas estéticas se combinam para engendrar novos possíveis, delineando outros relevos para arquiteturas mentais num contexto onde natureza e técnica estão cada vez mais indiscerníveis.

Nossa sensibilidade humana, demasiadamente humana, vem sendo estimulada e ampliada por novos prazeres sintéticos, toda uma diferenciada gama de sensações produzidas pelo cruzamento entre a inventividade humana e suas ferramentas tecnológicas. Não se trata de utilizar a tecnologia como um acessório, um gadget, ou como uma novidade por si só; trata-se de expandir nossos limites sensoriais, perceptivos e cognitivos, através da exploração de novas possibilidades de expressão.

O que a associação entre música e tecnologia parece tornar evidente é que é possível viver e fazer arte em harmonia com as máquinas: uma harmonia mais ampla que acolha o dissonante. Ao mesmo tempo, esta associação aponta para uma inesgotável potência do humano para se desdobrar em múltiplas fases, por contato e assimilação do que lhe é heterogêneo.

Em Psicologia, entendemos a percepção como a base da estrutura cognitiva, através da qual o ser vivo decodifica a exterioridade e se relaciona com o seu meio ambiente. A percepção é sempre interessada ao organismo. Os recortes perceptivos funcionam como mapas que orientam o vivo dentro da realidade caótica. Na obra de Deleuze encontramos a tematização da quebra do sistema sensório-motor de modo a fazer emergir perceptos e afetos, que seriam obliterados por uma apreensão organísmica da realidade. Segundo Deleuze, a arte deflagra perceptos, que não se confundem com a percepção 
que remete ao objeto, e afetos, que independem do estado do sujeito. Perceptos e afetos articulam-se à própria expressividade da matéria.

“O objetivo da arte, com os meios do material, é arrancar o percepto das percepções do objeto e dos estados de um sujeito percipiente, arrancar o afecto das afecções, como passagem de um estado a um outro. Extrair um bloco de sensações, um puro ser de sensações. ... os afectos são precisamente estes devires não humanos do homem, como os perceptos ... são as paisagens não humanas da natureza." 21

Deleuze e Guattari acentuam o potencial das artes para constituir novas cartografias para a subjetividade humana, o processo criador operando por contágio, abrindo fraturas no que já está estratificado e liberando intensidades em contra-fluxo com o presente sem espessura que a aceleração das tecnologias da informação parece eternizar. Este “eterno presente" é apresentado como uma mera sucessão de instantes, distinguindo-se do presente espesso do acontecimento, prenhe de gérmens de futuro e fímbrias do passado imemorial.

Segundo estes autores, a linguagem da arte não seria a linguagem de um sujeito/autor, mas um agenciamento coletivo de enunciação, que pode engendrar ressonâncias nas esferas individual e social. O esmaecer da figura do autor na contemporaneidade coincide com o enfraquecimento da noção de sujeito, do conceito iluminista de homem.

A atual discussão de conceitos como o de inteligência coletiva ou cognição distribuída, por exemplo, ressalta o aspecto maquínico do pensamento. Não mais concebido como um atributo exclusivo do sujeito humano, mas sim como resultante de agenciamentos entre mentes e máquinas, o pensamento sai da esfera do puramente individual e subjetivo e passa a ser enfocado a partir de suas inúmeras hibridizações, inclusive e sobretudo aquelas mediadas pela tecnologia.

${ }^{21}$ DELEUZE, G. Conversações. Op. Cit., págs. 217 e 220. 


\begin{abstract}
"A inteligência e a cognição são o resultado de redes complexas onde interagem um grande número de atores humanos, biológicos e técnicos. (...) O pretenso sujeito inteligente nada mais é do que um dos micro atores de uma ecologia cognitiva que o engloba e restringe. (...) Tudo o que for capaz de produzir uma diferença em uma rede será considerado como um ator, e todo ator definirá a si mesmo pela diferença que ele produz. (...) Os dispositivos técnicos são portanto realmente atores por completo em uma coletividade que já não podemos dizer puramente humana, mas cuja fronteira está em permanente redefinição.”22
\end{abstract}

Teóricos como o norte-americano Bruce Mazlish 23, por exemplo, propõem que a evolução de máquinas e homens faz parte de um só contínuum. Mazlish utiliza uma abordagem neo-darwinista para discutir sua concepção de uma natureza humana em constante evolução, enfatizando que a cisão entre homens e máquinas não se sustenta e situando os artefatos tecnológicos no phyllum evolutivo humano.

Ao explorar o espectro sonoro da música eletrônica ou eletroacústica, visamos melhor compreender algumas das mudanças nas posturas de escuta trazidas à cena através de agenciamentos entre humanos e máquinas. Como fio condutor nesta investigação, o conceito de inumano, o qual, segundo Lyotard, se impõe como a grande questão do contemporâneo.

\begin{abstract}
“Em 1913, Apollinaire escrevia ingenuamente: 'Os artistas são, antes de tudo, homens que pretendem tornar-se inumanos.' E em 1969, se bem que com um pouco mais de prudência, Adorno escrevia ainda: 'A arte mantém-se fiel aos homens unicamente pela sua inumanidade para com eles.' (...) e se, por um lado, os humanos, no sentido do humanismo, estão em vias de, constrangidos, se tornarem inumanos? E se, por outro lado, for ‘próprio' do homem ser habitado pelo inumano?”24
\end{abstract}

Estas indagações, que grifamos acima, nos levam a perceber que a noção de inumano presta-se a interpretações distintas, as quais convém esmiuçar aqui. De um lado, temos o inumano tomado negativamente, como aquilo que

${ }^{22}$ LÉVY, P. As Tecnologias da Inteligência, Rio de Janeiro: Editora 34,1995. págs. 135 e 137. ${ }^{23} \mathrm{Em}$ : The fourth Discontinuity: the co-evolution of humans and machines. New Haven: Yale University Press, 1993.

24 Lyotard, J. F. O Inumano: considerações sobre o tempo. Lisboa: Estampa, 1990 p. 10. Os grifos são nossos. 
não é da ordem do humano; sua alteridade, algo que a ele se opõe e, mais ainda, o ameaça.

Tal interpretação pressupõe o homem como uma forma estável e naturalmente pré-determinada. Desde o Iluminismo, os humanistas concebem a natureza humana como universal e previamente determinada, tendo sido a tensão entre natureza e cultura a questão preponderante dos pensadores modernos, a cultura afastando perigosamente o homem de sua natureza (pura, dócil) ou, ao contrário, refinando e afastando o homem de sua natureza bestial.

Por outro lado, podemos interpretar o conceito de inumano como constituinte do próprio engendramento do humano. Esta modalidade de interpretação está afinada com a compreensão do humano não como um jádado, mas como um eterno tornar-se; engendrado a partir de componentes heterogêneos que são o próprio suprimento da vida e da cultura. Nas palavras de Guattari, "Essa parte não humana pré-pessoal da subjetividade é essencial, já que é a partir dela que pode se desenvolver a sua heterogênese.”25

A obra de Deleuze e Guattari preocupa-se em apontar a imbricação entre natureza e cultura, convidando a uma apreensão transversal dos seus diversos modos de interação. A obra de Nietzsche, um libelo contra as naturalizações impostas pelo humanismo. Sua Genealogia da Moral ${ }^{26}$ pode ser lida como um dispositivo de desmonte destas naturalizações, concebendo a forma-homem como transitória e preconizando o surgimento do Übermensch, ou além-dohomem. Apesar de problemático, o fato das idéias de Nietzsche (assim como a música de Wagner) terem sido apropriadas por uma ideologia nefasta não nos parece desmerecer sua pertinência, seu brilho e seu vigor.

Em nossos dias, diante do esmaecimento do conceito iluminista de natureza humana no bojo de um contexto em que natureza e técnica estão cada vez mais indiscerníveis, constatamos a importante relevância da noção

\footnotetext{
25 Félix Guattari em Caosomose: um novo paradigma estético. Op. Cit. p. 20.

26 São Paulo: Moraes, 1991.
} 
do inumano, este agindo com uma espécie de reserva de psico-sociodiversidade que nos constitui e que nutre nossos devires possíveis.

O questionamento da predisposição dita natural do ouvido humano à tonalidade - que ensejou o desenvolvimento da música atonal de Shöenberg, o serialismo de Webern e o experimentalismo de Varése - foi, a nosso ver, um modo de comparecimento do inumano na música ocidental. Este viés inumano na música se prolonga até hoje através das mais diversas tecnologias do som, as quais, como afirmamos, vêm marcadamente modificando nossa sensibilidade. Como exemplos pioneiros, a música eletrônica de Stockhousen, Berio, Boulez, etc; a vertente concreta de Shaeffer; ou a computer music de Cage.

Esta noção de inumano nos leva a uma investigação das transformações operadas na linguagem musical e na sensibilidade do ouvinte atual com a entrada em cena de novos meios digitais de produção, difusão e reprodução do som. O escopo destas transformações apenas começa a ser inventoriado²7.

Quando apocalípticos proclamam o fim da arte com a morte das vanguardas enquanto a banalização viceja em um espaço cultural tornado mercado, parece haver um coeficiente que resiste a esta trivialização e ao mesmo tempo investe na exploração expressiva dos novos meios, produzindo novos sentidos possíveis.

\footnotetext{
"O significado da arte pós-moderna, pode-se dizer, é estimular o processo de elaboração do significado e defendê-lo contra o perigo de, algum dia, se desgastar até uma parada; alertar para a inerente polifonia do significado e para a complexidade de toda interpretação: agir como uma espécie de anticongelante intelectual e emocional, que previna a solidificação de qualquer invenção a meio caminho para um cânone gelado que detenha o fluxo de possibilidades." 28
}

\footnotetext{
27 Nossa pesquisa atual Web Music: novas posturas de escuta na cultura contemporânea, sediada no Programa de Pós-Graduação em Comunicação Social da PUC-Rio, pretende contribuir para este mapeamento ao focalizar a associação entre música e microinformática, segundo o aspecto da recepção.

${ }_{28}^{8}$ BAUMAN, Z. O Mal-Estar da Pós-Modernidade. Rio de Janeiro: Jorge Zahar Ed., 1998. pág. 136.
} 
No caso da música, esta "polifonia do significado" - a qual em razão do rigor preferimos aqui denominar polifonia do sentido, dá lugar a uma pluralidade de tramas no tecido musical - onde hoje são re-processados sons naturais e sintetizados, ruídos e silêncio, erudito e popular, texto, som, iluminação e cena - expandindo e enriquecendo a linguagem musical devido à contínua e consistente ruptura com marcadores preestabelecidos, tornando sua fruição parte integrante da experimentação artística.

Podemos afirmar que estas contribuições da música contemporânea se situam no bojo das experimentações que vêm compondo novas modalidades de apreensão desta polifonia do sentido, que requer posturas de escuta diferenciadas.

Durante sua longa carreira, o compositor John Cage foi um intransigente defensor da instauração do que chamou uma nova escuta (new listening). Artista e pensador polêmico, pioneiro na criação de uma nova linguagem musical experimental, para além da tonalidade, Cage lançou inúmeras indagações acerca do sentido da arte e da música em especial, convidando o ouvinte a desenvolver novas posturas de escuta.

Suas indagações apontam para a constituição de modalidades de escuta que sejam permeáveis ao estranhamento, arriscando o confronto com o diverso. A forte influência da tradição melódico-harmônica leva o senso comum a considerar musicais apenas os sons que obedecem a esta tradição. Desta forma, sons híbridos, acordes dissonantes, texturas sonoras complexas tendem a escapar à compreensão e ao interesse mais imediato.

Graças à inventividade e plasticidade do humano, as formas de arte estão em incessante processo de modificação, assim como seus próprios modos de recepção, na medida em que o humano é simultaneamente sujeito e objeto das transformações culturais.

Ao analisarmos a formação de novas posturas de escuta no contexto cultural contemporâneo, situamos na eletrificação do som dois momentos que nos parecem bastante significativos. No primeiro momento as tecnologias de 
telecomunicação mediaram as distâncias entre emissor e receptor tornando possível o que Murray Schaeffer denomina esquizofonia. Isto que hoje nos parece natural marcou uma modificação essencial na experiência do ouvir ao estender o alcance de nossa escuta e ao transformar drasticamente nossa ambiência sonora.

Num segundo momento situamos a amplificação e alteração do som através da eletricidade. Com a amplificação nosso senso de escuta foi prolongado, passando a captar atividades sonoras em níveis até então inaudíveis. O padrão da voz cantada mudou, passando a contemplar modalidades de interpretação mais conversacionais ou intimistas. Sutilezas, pequenos detalhes do arranjo musical tornaram-se mais pregnantes aos nossos ouvidos.

Graças à amplificação, passamos a conviver com dinâmicas de som antes raras ou mesmo inalcançáveis acusticamente em música. Nestes casos o ouvir música transforma-se em uma experiência sensorial de imersão no som - um deslocamento que parece atingir proporções quase incomensuráveis.

Da mesma forma, a extraordinária alteração da tímbrica sonora com a entrada em cena dos instrumentos musicais eletrificados ensejou transformações marcantes. Recursos como reverberação e distorção, por exemplo, aliados à amplificação, passaram a fazer parte integrante do universo dos sons considerados musicais. Ao adentramos a ambiência dos sons sintetizados, combinados e processados eletronicamente, nossa escuta passou a conviver com nuances sonoras cujo espectro e complexidade apenas começa a se descortinar.

Apesar de sermos um país notadamente musical, o Brasil carece de mecanismos mais eficazes de divulgação de sua produção musical mais experimental e recente. Vivemos em uma sociedade, falando em termos de sua ínfima porção mais privilegiada e culta, que vê com maus olhos quem não conheça vertentes mais contemporâneas de literatura, cinema, dança, teatro 
ou artes plásticas. Entretanto tolera-se bem o desinteresse pelo que se tem feito no terreno da música de concerto em nossos dias.

Talvez a música seja mesmo diferente. Por ser, ainda que injustamente considerada passiva, a audição tende a ser encarada como natural e poucos consideram o lado extremamente ativo e seletivo da experiência da escuta.

O hábito de ouvir música como entretenimento ou mero plano de fundo, tem como conseqüência uma desatenção aos aspectos acusmáticos da experiência de escuta. Ouvir, neste caso, assemelha-se a não-ouvir, conhecer passa a ser re-conhecer. Algo semelhante ocorre também com a visão. Como dissemos, todo o esforço da arte contemporânea, parece-nos, tem sido no sentido de romper com os sistemas de representação e forçar os sentidos para além do amortecimento do hábito.

Nossa discussão acerca das novas posturas de escuta desenvolvidas a partir da associação entre música e tecnologia apontou para uma dramática desnaturalização do ouvido humano. Ressaltando o papel ativo do ouvinte, verificamos que a sensibilidade humana, longe de ser natural e portanto acabada e imutável, expande seu potencial sensível ao ser estimulada sinteticamente, dando origem a novas possíveis configurações de sentido.

O presente artigo pretendeu apresentar, ainda que de forma breve, algumas das principais idéias que sustentam a pertinência da investigação acerca da recepção musical nas práticas culturais contemporâneas.

\section{Bibliografia:}

BAUMAN, Zygmunt. O Mal-Estar da Pós-Modernidade. Rio de Janeiro: Jorge Zahar Ed., 1998.

BENNEDETTI, Paul e DeHART, Nancy. Forward Through the Rearview Mirror: Reflections On and By Marshall McLuhan. Ontario: Prentice-Hall, 1992.

CASTELLS, Manuel. A sociedade em rede. S. Paulo: Paz e Terra, 1999. CASTRO, Gisela G. S. As Canções Inumanas: música, tecnologia, escuta e comunicação. Tese de Doutorado (mímeo). Orientação: Liv Sovik. ECO/ UFRJ, 2003. 
DELEUZE, Gilles. Conversações. Rio de Janeiro: Editora 34, 1992. e GUATTARI, Félix. O Que é a Filosofia? - Trad. Bento Prado Jr. e

Alberto Alonso Muñoz S. Paulo: Ed. 34, 1993.

- Mil Platôs. Vols. 1 a 5

e PARNET, Claire. Diálogos. Trad. Eloísa Araújo

Ribeiro. São Paulo: Ed. Escuta, 1998.

DERY, Mark. Escape Velocity: cyberculture at the end of the century. New

York: Grove/Atlantic, 1995.

DOMINGUES, Diana (org.). Arte e Tecnologia no Século XXI: A Humanização das Tecnologias. S. Paulo: UNESP, 1997.

GUATTARI, Félix Caosmose: um novo paradigma estético

e ROLNIK, Suely. Micropolítica: cartografias do desejo.

Petrópolis, RF: Ed. Vozes, 1986.

KERCKHOVE, Derrick de. A Pele da Cultura: Uma Investigação Sobre a Nova Realidade Eletrônica. Lisboa: Relógio D’Água Editores, 1997.

LÉVY, Pierre. Cibercultura. Rio de Janeiro: Ed. 34, 1999.

As Tecnologias da Inteligência: o futuro do pensamento na era

da informática. Rio de Janeiro: Editora 34, 1995.

LINS, Daniel (org.). Cultura e Subjetividade; saberes nômades. Campinas, SP: Papirus, 1997.

LYOTARD, Jean-François. O inumano: considerações sobre o tempo. Lisboa: Estampa, 1989.

MAZLISH, Bruce. The Fourth Discontinuity: the co-evolution of humans and Machines. New Haven: Yale University Press, 1993.

McLUHAN, Marshall. Understanding Media. Cambridge: MIT Press, 1992. \& FIORE, Quentin. The Medium is the Massage: an

inventory of effects. Toronto: Bantam Books, 1967.

PESSOA, Fernando. Obra Poética. Rio de Janeiro: Aguilar, 1996.

RHEINGOLD, Howard. The Virtual Community: homesteading on the

electronic frontier. San Francisco: William Patrick Book, 1993-2000.

SCHAFER, R. Murray. Creative Music Education. N. York: Schirmer Books, 1976. Editado no Brasil como O Ouvido Pensante. S. Paulo: EDUNESP, 1991.

SODRÉ, Muniz. Antropológica do Espelho: uma teoria da comunicação linear e em rede. Petrópolis, RJ: Editora Vozes, 2002.

TAVARES D'AMARAL, Marcio (org.). Contemporaneidade e Novas

Tecnologias. Rio de Janeiro: Sette Letras, 1996.

TURKLE, Sherry. Life on the Screen: Identity in the Age of the Internet. New

York: Simon and Schuster, 1995.

WERTHEIM, Margaret. The Pearly Gates of Cyberspace: a history of space from Dante to the Internet. New York: Norton, 1999. 